\title{
$\uparrow$ \\ THE COMMUNIST INSURGENT INFRASTRUCTURE IN SOUTH VIETNAM: \\ A STUDY OF ORGANIZATION AND STRATEGY
}

\author{
by \\ Michael Charles Conley
}

Research and writing completed: November 1966

CENTER FOR RESEARCH IN SOCIAL SYSTEMS

The American University

Washington, D. C. 20016

Operating Under Contract With

The Department of The Army 